\title{
Picking up the pieces: social capital and entrepreneurship for livelihood recovery among displaced populations in Northeast Nigeria
}

\section{Oluwaseun Kolade, Gaim Kibreab, Saliba James \& Robert Smith}

In the past few decades, there has been a significant increase in the rate of forced displacement, often precipitated by persecution, civil wars, terrorism, transborder conflicts, as well as natural disasters. The United Nations High Commission for Refugee (UNHCR) reports that there are 25.4 million refugees and 68.5 million forcibly displaced people, and only a small fraction are able to return to their former homes (UNHCR 2019). Boko Haram insurgency in Nigeria has precipitated humanitarian tragedy on a scale comparable to the Nigerian civil war (1967-1970) and arguably the worst of any manmade or natural disaster in Nigeria's history. The Internal Displacement Monitoring Centre estimates that up to 3.3 million people have been internally displaced due to terrorist violence perpetrated by the Boko Haram (International Displacement Monitoring Centre 2015). The number of people displaced by the conflict is the largest in Africa and the third largest in the world. Using quantitative and qualitative data obtained from questionnaires and interviews conducted with respondents in Northeast Nigeria, the study examines the extent to which the displaced populations are drawing on social capital and human capital to withstand, cope with and recover from the adverse experiences and consequences of the insurgency and counterinsurgency.

Given that most forced displacements occur in developing countries like Nigeria, government resources are increasingly stretched to deal with the crisis, and there are calls for fundamental rethink of the traditional approach to interventions in disaster situations. In particular, scholars and practitioners are highlighting the need to shift from the current emphasis on technological solutions and financial input, to an approach that combines both technological solutions and social solutions, bringing people and communities to the forefront of interventions (Aldrich \& Meyer 2014; Wind \& Komproe 2012; Johnson et al. 2013). Forced migration is a social process in which human agency and social networks play a major part. These networks can be instrumental in the construction and (re)-construction of livelihood systems and communities shattered by insurgencies and protracted conflicts.

\section{Methodology}

This paper draws on archival documents and in-depth interviews to explore how social networks and individual skills are operationalised as critical survival resources among displaced populations in Northeast Nigeria. We then propose a conceptual framework that illuminates the role of social capital as a driver of entrepreneurship among displaced populations, and how entrepreneurship can play a key role in livelihood recovery. Detailed empirical findings will be reported in the full paper.

\section{Study context}

Northeast Nigeria is one of the six geopolitical zones in the West African nation, and it comprises of six states: Adamawa, Bauchi, Borno, Gombe, Taraba, and Yobe. It is the poorest geopolitical zone in the country, and the region with the highest levels of illiteracy and unemployment. In 2002, the terrorist group Boko Haram was formed in Maiduguri, Borno State, by the radical cleric Mohammed Yusuf. Its official name is Jamaatu AhlusSunnahLidda Awati Wal Jihad, the Arabic for "People Committed to The Prophet's Teachings 
for Propagation and Jihad". Its popular name, Boko Haram, derives from its core teaching that western education is forbidden (Adesoji 2010)

Borno State, the epicentre of the Boko Haram insurgency, has an estimated population of 5.2 million and a landmass of $61,435 \mathrm{~km} 2$, the largest state by landmass in Nigeria. Borno State lies between latitudes 100 and $140 \mathrm{~N}$, and longitudes 110 30' and 140 45' E (University of Maiduguri 2009). It is bordered by Niger Republic to the North, Chad to the North East, and Cameroon to the East. Within Nigeria, it shares borders with other Northeastern states of Adamawa, Yobe and Gombe states. Maiduguri is the capital city of Borno and the largest city in Northeastern Nigeria, covering an area of $543 \mathrm{~km} 2$, and with an estimated population of 1 million (Mayomi \& Mohammed 2014).

\section{Preliminary discussion and theoretical framework}

Although there has been a surge of interest in the phenomenon of social capital and how it may influence and improve the development process (Lautze \& Raven-Roberts 2006), the literature on social capital and how it interacts with violent conflicts, especially in the context of intrastate wars still remains limited. Unlike in inter-state conflicts in which the need to confront an external national enemy fosters national unity and strengths social cohesion, intrastate conflicts generally result in the weakening of the social fabric of the communities concerned. Such violent conflicts often divide populations by eroding interpersonal and communal group trust and weaken or even destroy the social norms and values that underpin cooperation and promote collective action in pursuit of common interest. Erosion of social capital lies at the heart of communal strife. Not only does the destruction of social capital increase the likelihood of violent conflict, but this can also hamper the process of reconciliation and recovery after cessation of hostilities. Without the restoration of social capital, provision of other forms of capital is unlikely to promote economic and social development in post-conflict societies (Uphoff \& Wijayaratna 2000; Grootaert 1998; Uphoff 2000)

As used in this study, social capital refers to systems that result from social and economic organisation, trust, solidarity, shared values and norms of reciprocal cooperation, informational and economic exchange, and informal and formal groups and associations (Grootaert 1998; Uphoff 2000; Uphoff \& Wijayaratna 2000; Putnam 1994; Putnam 1995; Putnam 2001). Social Capital is recognised as a key livelihood asset in the sustainable livelihood framework, by means of which individuals and communities can overcome vulnerabilities by transforming structures and processes to achieve livelihood outcomes (Krantz 2001) Social capital is classified into bonding social capital between people with similar socio-economic characteristic and family and religious identities; bridging social capital among people belonging to different ethnic, social and religious groupings; and linking social capital between citizens and those in authorities (Claridge 2013).

The large-scale displacement in northeast Nigeria is caused by neither inter-state nor intrastate violent conflict. It is rather the result of terrorism that affects every segment of the communities in the areas affected by the Boko Haram insurgency. This situation offers a unique opportunity to examine the effect of violence on social cohesion and mutual trust and cooperation among the affected communities and also in terms of whether severe crisis faced in common by diverse communities engenders social bonds reflected in mutual trust and norms of reciprocity. Although the impact of the insurgency might have been differentiated at the initial stage of the conflict, currently, it seems that all the communities 
in the impacted areas are to a large extent affected detrimentally. If that is true, the communities may set aside their pre-existing differences to face a common enemy. This is likely to foster inter-communal harmony and cohesion which are critical to the development and utilisation of bridging social capital. This, however, is an empirical question which cannot be determined a priori.

Scholars have also highlighted the need to put human capital at the heart of development interventions. One of the leading figures of modern human capital theory, Theodore Schultz, observed that there was an apparent contradiction between the assumption of donor countries that poor countries are poor mainly because they lacked capital, and the views of experts that poor countries have low rate to absorb additional capital. According to Schultz, this apparent contradiction can be resolved with emphasis on particular forms of capital. Most development aid are provided in the form of financial--grants, loans, etc--or physical-structures, equipment, inventories- capital. There is little or no investment in human capital. As a result, 'human capabilities do not stay abreast of physical capital, and they do become limiting factors...' (Schultz, 1961).

Human capital is defined as "the aggregation of the innate abilities and the knowledge and skills that individuals acquire and develop throughout their lifetime" (Laroche \& Ruggeri, 1999, pp.89). It is acquired and developed mainly through formal education, on-the-job training and other informal means (Acemoglu \& Autor, 2011; Becker, 1964; Schultz, 1961) Although formal education is regarded as the principal source of human capital, latter researchers have also drawn attention to the importance of innate abilities, which are "defined as all physical, intellectual and psychological capacities that individuals possess at the time of their births" (Laroche \& Ruggeri, 1999, pp. 89). The aggregate stock of human capital- in educational qualification, vocational skills and talents- are effective drivers of entrepreneurial performance, especially in turbulent environments. This complements the role of social capital, in terms of opening access to new markets and facilitating new linkages with suppliers and other key actors in the entrepreneurial ecosystem. In turn, entrepreneurship is known to have transformative impacts in conflict situations by facilitating increased transactions and lowering outgroup prejudice in multi-ethnic and multi-ethnic communities and other similar contexts (Tobias, Mair and Barbosa-Leiker, 2013).

\section{Conclusion and practical implications}

Traditional, mainly material approaches to interventions in disaster situations have come under increased scrutiny in recent years because they have failed to deliver desired longterm outcomes and have encountered resource and capacity constraints in the face of continually expanding humanitarian crises. The study therefore examines the extent to which the displaced populations are drawing on social and human capital to withstand, cope with and recover from the adverse experiences and consequences of the insurgency and counterinsurgency. This can point to opportunities and methods for humanitarian actors to stimulate social and human capital among crisis-affected people purposively as part of their interventions, with the aim of better outcomes and value for aid money. 